\title{
Study on Current Public Opinion in Vietnam Based on Universally Value System and Core Values Approach
}

\author{
Phan Tan \\ Vietnam Academy of Social Sciences, Hanoi, Vietnam \\ Email: phantanxh@gmail.com, trungmuu@gmail.com \\ Received 12 January 2015; accepted 6 February 2015; published 11 February 2015 \\ Copyright (C) 2015 by author and Scientific Research Publishing Inc. \\ This work is licensed under the Creative Commons Attribution International License (CC BY). \\ http://creativecommons.org/licenses/by/4.0/ \\ c) (i) Open Access
}

\begin{abstract}
The history of Vietnam Country's formation and defense through thousands of years has been summarized in the modern society's objective value systems that are: independence, freedom, happiness, prosperous people and strong country, democracy, justice, and civilization. The value of democracy is regarded a core value and it has been realistic by applying the mechanism of the fact that the people know, people discuss, people do, and people supervise. The author looks forward to clarify this mechanism, and, above all, in a certain degree of clarification it matches with manner forming public opinion, the roles and functions of the public opinion.
\end{abstract}

\section{Keywords}

Public Opinion, Value System, Core Value, Regulation of Democracy, Development Goals

\section{Rationale}

The history of Vietnam Fatherland's formation and defense through thousands of years has been summarized in the modern society's objective value systems that are: independence, freedom, happiness, prosperous people and strong country, democracy, justice, and civilization. Based on such values system, every action by humans and the community for social development shall be evaluated, judged, and supported or rejected by the people. The values are interrelated in a dialectical way. The value of democracy is regarded a core value and it has been realistic by applying the mechanism of the fact that the people know, people discuss, people do, and people supervise-it matches with manner forming public opinion, the roles and functions of the public opinion.

Public opinion is a realistic spiritual structure. It has existed reflects of society and has expressed the spirit of social life. Social actions are determined by values. Therefore, they are evaluated and judged by the people 
based on values and standards. Thence, they orient or adjust social actions in line with built-up values or gradually change viewpoints on values to make them relevant with development in social—age perception.

Value system is understood as the blend of the community's life conception and the luggage that obviously each member takes in life. The value system orients each member's thoughts and actions.

Many Vietnamese scientists have approached values by ethical, cultural, socioeconomic, tangible-intangible heritage, and tangible —intangible value perspectives, etc.,. There is a study on Vietnam nation's spiritual value system by hierarchy of patriotism, diligence, heroism, creativity, optimism, compassionateness, and uprightness [1]. There is another study on proposals to build up a common value system for the Vietnamese in the current age from commonality to individuality: the world common values, the global values, national, family, and individual values [2] [3].

In addition to individual studies, Ho Si Quy (2005) has drawn a hierarchy of value with hallmarks of studiousness, industriousness, community, and hematology, etc., influenced by Confucianism in the fluctuation of globalization by approaching Asian sense of values in general characteristic of humanity. Regarding to Vietnam particularly, he emphasizes on the sense of community as "a fundamental value in the entire Vietnamese personality culture" [4].

Based on the approach to objective value system identified and oriented universally that Vietnam has been moving toward: independence, freedom, happiness-prosperous people, strong country, democracy, justice, civilization, our basic study aims at the roles and functions of public opinion in shaping the society towards the true value!

\section{Value System and Goals of Vietnamese Nation}

During the long history of Vietnamese nation, with thousands of years under Chinese domination, dozens of wars against foreign aggression and defending the nation, countless civil wars, separations, conflicts etc., the will of independence, freedom and happiness has gone into the subconsciousness-consciousness of the nation, consciousness of the Vietnamese. Being the Vietnamese, everybody is proud of nation defending traditions; everybody wishes Vietnam to be peaceful, stable and prosperous than ever and have equal status in the world.

In parallel with the long history of gaining and maintaining the national independence and development through ages; in the integration trend from primitive to modern ages, the objective intrinsic values for development, such as: prosperous people, strong country, democracy, justice and civilization, have also been developed gradually to complete both theoretically and practically ${ }^{1}$.

Every social behaviour and movement are shaped and referred to desired values. Basic value system central values (Independence-Freedom-Happiness) and development value system (Prosperous people-Strong country-Democracy_Justice-Civilization) have become a pair of value which means to be both tangible and intangible assets. This pair of value has dominated the entire social behaviour. Whether each social phenomenon, each event, each social issue happens on behalf of anything, it cannot go beyond the general reference range of this pair of values. The social behaviour, whether positive/negative, good/bad, development/anti-development, will be evaluated and judged by the community itself based on this pair of values.

To protect the value system of "Independence-Freedom-Happiness", Vietnamese has to prioritized solidarity and consensus first whenever there is invader. It has become a source of internal strength of the country whose greatest achievements were to prevent from China's cultural assimilation and annexation (when many states, which are now China's autonomous regions ${ }^{2}$, could not do). Even more importantly, the defense for territorial integrity — national independence has been proven throughout the national history, such as: Southern Han's domination defeat by Khuc Hao and Ngo Quyen (in 913, 938), Ly Dynasty's two victories over Tong's military (in 981, 1075-1077), Mongolia's defeat three times by Tran Dynasty (in 1258, 1285, 1287-1288), Le Loi's resistance movement against the Minh Dynasty (1418-1427), following with Quang Trung's great victory over Manchu military (1788-1789), etc. They have been major milestones in the history of defense for national independence and freedom.

To consistently develop with ages, extensively integrate with the world, and ensure human and ethnic rights,

${ }^{1}$ In Ho Chi Minh era (from the beginning era of Vietnam, from 1945 to the present provisionally), every value of "Independence- Freedom-Happiness" and "Prosperous people—Strong country—Democracy—Justice-Civilization", every new development goal is gradually developed theoretically and recognized its legitimacy.

${ }^{2}$ Inner Mongolia, Tibet, Xinjiang Uyghur, Bach Viet... were states which Chinese annexed and assimilated by force and culture. In the most recent case in history, Manchu people came to rule Chinese but eventually were assimilated by Chinese. 
the value of Prosperous people-Strong country-Democracy—Justice-Civilization is recognized, analyzed, promoted, inspected, monitored, and opposed by the community and society. Not only local communities but also international organizations and institutions monitor and oversee the value's practices.

As the prosperity of the country, the rights to live, work and learn in a healthy, civilized environment have become the ultimate goal to be achieved and preserved by the whole community. Every social behaviour and action to protect or infringe that social value will be praised or condemned or judged. This is the compound of opinions with people's understanding, participation in community, responsibilities to preserve the values and individuals' interests in the community [5].

\section{Value System and Core Values in Orientation of Public Opinion in Vietnam}

When it comes to public opinion, so far, there have been hundreds of definitions and every definition is rational based on the researcher's approach. Through the survey, evaluation, integration of public opinion concepts, we believe that: Public opinion is a complex of discussion, reflection, evaluation, recommendation, claim, solution of social groups on the social issues happening related to concerned benefits and values.

From the above definition, we can fully understand public opinion under the following aspects:

1) Public opinion is the compound of ideas interacting with one another through the process of discussion to show awareness, emotion and will of the social groups. Discussed personal comments become general opinions and individuals become public opinion carriers.

2) Public opinion may only be evaluation, judgment, recommendation or claim, solution. When the public has only evaluated, judged and not provided recommendation, claim or solution, then the public opinion conditions are not fulfilled. Public opinion can be different or even contrary, which form similar or different comments.

4) Public opinion may be the opinion of majority or minority. That opinion is debated and consented based on benefits and/or values of their interests.

5) Only social issues, events, phenomenon related benefits of many people's interests are capable of creating public opinion (benefit is the basis of debate).

6) Values and standards serve as a basis for public opinion.

So, how is the value which public opinion discusses, reflects, evaluates, recommends, claims, solves in Vietnamese's pair of value shown?

\section{Democratic Values in Practices-The Role and Function of Public Opinion Nowadays}

Vietnamese history also records milestone of representative democratic spirit which took place under Tran Dynasty. At that time, in order to turn the King and generals' ideas and will into people's strength to fight the $2^{\text {nd }}$ Mongol's invasion, King Tran Nhan Tong (1258-1308) invited all country's elders to the Citadel to attend Dien Hong Conference (1284) to discuss strategies to save the country. This is a model of democratic activities in asking people's opinions and creating public opinion and power from people's beliefs. Dien Hong Conference is considered as the first democratic conference in Vietnamese history. The elders might have been regarded as representatives to the people. After the conference, the elders were those who conveyed the policy of the Royal court to the people.

To protect and promote values in order to achieve development objectives and be consistent with the era; simultaneously, to ensure community benefits, to limit group benefits are the entire community's responsibilities. However, the state plays a special important role in orienting the development, ensuring the preservation of values, promoting social activities to achieve goals. But the most important thing is giving people their real rights to mastery to actually decide all the development, protection and promotion of values.

The issuance of "Grassroots Democratic Regulations" (1998) by Vietnamese government was an important step to hand people their real rights to mastery. People's rights to decide the development are shown in 4 action mottos: People know—People discuss—People do—People supervise [6].

Democratic regulation at grassroots level shows that the elements of "people know, people discuss, people do, people monitor" have dialectical relationships. It begins by providing information and ends by controlling and supervising for the final conclusion. It is suitable for pathway of forming public opinion and the role and function of public opinion:

-People know: publicly and transparently inform all social events and issues taking place; individuals in so- 
cial community are exposed, familiar, directly witness or hear about things, events, phenomena occurring in society.

If you want people to know, you have to provide them information. People have the right to be provided with information to evaluate the situation and indicate their attitudes in the process of forming and expressing public opinion. Information must be honest and timely. "People should be able to know all country's matters which are relevant to their interests and the publicity will not prejudice the national interests" [7]. The provision of information to people is for implementing the publicity of "saying the truth". Only by this way, the social evaluation of public opinion can reflect the social statuses of the problems that create creating a common concern.

-People discuss: people openly discuss and exchange their opinions to find the most common opinion; personal opinions are shared, exchanged and discussed together in social group.

Public opinion reflects opinion of the majority. Thus, "people's discussion of the information they receive is an important factor to multiply the proportion of the reasonable discussed opinions" [7]. Discussion will retain and emphasize the common and principal, dismiss what is not fundamental and form a common opinion, express people's general concern about phenomena and things.

The criticism activity that we are expecting in the socio-political organizations with Vietnam Fatherland Front to be the central institution is the official form of public discussion. It has some certain effects, contributes in creating social consensus, gathers common will of society, and creates the necessary actions for the development. However, the expansion and promotion of democracy in social criticism, in order to avoid consenting and forcing forms, "people must have real voice" and this voice firstly is the voice of the intellectual elite and elders. If this voice is spoken strongly, there will be a large force to supervise and prevent negative social behaviours by public authorities as well as individuals and other social organizations.

Thus, people can discuss solutions in many different forms and by many different communication channels; they can experience, exchange, consider sides, advantages and disadvantages, pros and cons, new and old, good and bad with the trend of compliment or criticism, support or opposition, acceptance or reject. Everyone change their thoughts and personal opinions by accepting and sharing the best and most reasonable solution amongst workarounds suggested.

-People do: overall public evaluation (opinion) is the basis for practical action of the masses.

In terms of awareness, public opinion is a mental—realistic structure, it is not only socially conscious, reflects social shortcomings but also through social evaluation of the phenomena and events, it becomes the premise for practical actions to promote or restrict a certain social phenomenon or event in a direction consistent with the majority's interests.

"People do" is a step to express the evaluation of public opinion in practice. "People do" is an expression of the social action of the population group, social classes on the basis that they are all provided with information and evaluate social situation, phenomenon, and issue through collective discussion.

In here, the issue of "words go with actions" is very important. If the guidelines and policies set forth are true but not applicable in practice, specifics task and actions which are consistent with it are not passed, i.e. "just say without action" or "speak one way and act another", then desirable social effects cannot be made.

-People supervise: results of public opinion along with practical action.

Public opinion is formed officially and/or unofficially. Supervising activities in relation to public opinion also take place according to this mechanism. Because public opinion is formed under the domination of the social values and norms, when being formed, public opinion turns to affect social values and norms. Public opinion also controls and inspects the apparatus State and leading officials unofficially to see whether their activities are in accordance with the collective interests or not. It is necessary to detect problems to help judicial authorities and law enforcements to execute their tasks well.

Control function of public opinion has a positive meaning in this activity. Any social action is checked, monitored until there is a final result. Public opinion gives praise and support to behaviours that deems to be in accordance with standards, correct and condemn acts of violating norms.

\section{Ensuring Values, Aiming to Develop-Orient Healthy Public Opinion}

In living activities, all individuals and groups must learn social values and norms in order to survive. The values are recognized as the importance for the group or community. However, when complying with values, members sometimes do not follow the rules to meet the expectations of the group or community. The specific values such 
as career, money, power... have always been seen as being limited or scarce which make them into objects for competition and conflict. So, in order to stabilize society, there should be a mechanism to control and adjust members to comply with group values.

One of the causes of social conflict is differences in awareness, protection of value and benefits. Conflicts usually derive from a normal phenomenon at the beginning, and then arise due to differences of opinion of value and benefit, due to the enjoyment of value and benefit. The role and function of public opinion towards life is undeniable, and public opinion covers all social areas and relationships. Public opinion participates in discussions, judgment and evaluation; and is turned into the public's practical action in all activities in order to protect the personal and social value and benefit.

Currently, we are facing the conflicting problem of this pair of values: 1) Extreme, nationalist notion of independence, limiting external cooperation which conflicts with notion of expansion, integration, development, recognizing soft borders. 2) Notion of absolute freedom conflicts with notion of freedom within legal framework in order to keep the stability. 3) Notion of achieving national prosperity by prioritizing rapid growth conflicts with notion of sustainable development harmonizing between growth and sustainable development. 4) Notion of gradually practice democracy, stability, controlled democracy that conflicts with democracy on all sides, especially freedom of speech.

The issue here is the need to reconcile these contradictions when it comes to settling the benefits to individuals, groups and communities. Public opinion orientation is to gradually regulate conflicts, reconcile notions towards solution of "Reconcile" all opposites in a contradiction.

Recognizing the role of public opinion, the Vietnam Communist Party has considered capturing people's heart (people's thought, desire and will) to be one of the important works right from its inception in order to propose revolution guideline which are appropriate to people.

Many documents and decisions of the Party leadership authorities have confirmed the role of public opinion study. As early as 1982, the Secretariat decided to establish the Institute for Public Opinion under the Party Central Department of Propaganda and Education, which contains provisions on the responsibilities and authorities, "Institute for Public Opinion is responsible for organizing the study of public opinion on basic problems of the country and the important issues typically in Marxist—Leninist standpoint; synthesizing, analyzing public opinion to report to the Party and State authorities; organizing, training and retraining of informants and collaborators of the Institute theoretically and professionally. The institute is allowed to directly relate to the party committees, agencies and mass organizations to organize public opinion study” [8]. Also in some hubs such as institutes for social study directly under the Vietnam Academy of Social Sciences, universities have established departments, disciplines of public opinion but are still fragmentary.

In early years of renewing (from 1986) and especially recently, the Vietnam Communist Party have continued to strengthen the leadership of sociological investigation, capture public opinion, such as: Documents of $3^{\text {rd }}$ plenum by $7^{\text {th }}$ Central Executive Committee on innovation and regulation of the Party has mentioned the tasks for ideological work: "To improve the quality of internal information and propaganda, to value measures of public opinion surveys" [9]. In the 8th plenum by the 7th Party Central Executive Committee on building and perfecting the Socialist Republic of Vietnam, it is required: "To investigate public opinion on matters necessary for leading and managing the State to build law on national referendum” [10]. Resolution of 5th plenum of the 10th Party Central Committee on the work of ideology, theory and journalism for new requirements, further emphasized: "To focus on sociological study and survey, to capture public opinion in order to serve ideology work” [11]. Most recently, in order to enforce the resolution of 4th plenum of 11th Party Central Committee on some urgent issues in building Party currently, the Politburo issued Plan no. 08-KH/TW dated 12/03/2012 which directs, "To innovate and improve the quality of public opinion surveys, to gather opinions of officials, Party members and people to refer to before making Party and State's policy decisions” [12].

On the Vietnam Government side, in 2005, in information development strategy until 2010, the Government also issued Decision No. 219/2005/QĐ-TTg of the Prime Minister, one of the strategies mentioned was "To complete coordination method and mechanism to efficiently handle the feedbacks which people contribute, reflect to the Party and the State; to improve the quality of public opinion surveys; to strengthen external information systems, to actively fight wrong and hostile notions" [13].

Thus, the study and capture of public opinion are more or less guaranteed by the ruling party's pathway and policy. In the role of public opinion, the institutional problems in protecting and promoting values, promoting social activities to achieve goals are enhanced. However, in reality, the legitimacy of the State's study and cap- 
ture of public opinion still have many problems. Individuals in the community are afraid of public opinion, highly appreciate or aware its power, and many public officials avoid public opinion. But in fact, public opinion does not really come to life in order to promote effective implementation of function and role since on the state side, we have not really had institutions which prescribe results of the study and capture of public opinion. Therefore, an important issue is the need to have a complete legal system with the main law namely the Law on Referendum. Law on Referendum is the legal basis for public opinion study; moreover, it is necessary to assert the right to approve of the entire population (all citizens) in the Constitution as the general fundamental law of the law system and as the civil society indenture.

Public opinion evaluates, protects and develops value; public opinion's evaluation, protection and guarantee of justice in benefits are expectations of all those who know, understand, study, capture and orient public opinion. It does not matter what, in Vietnam society today, in order to ensure a healthy social environment in which public opinion is actually promoting its role and function, there are some key issues which should be noted:

1) To determine the limit, principles, rules, relations between the state and people; with particular focus on clarify and publicizing administrative procedures, mechanisms and policies in general; to create effective mechanisms for people to participate in State and social management, and monitor the State's activities; freedom of speech under the law and in respect of public opinion.

2) Scientific and social criticism should become regular activities; there should be mechanisms for all people, of all social organizations involved in building decisions, especially when it directly relates to the benefits of their lives.

3) To build civil society, to create opportunities for these organizations to independently supervise independent state; to organize discussion forums and public opinion surveys, referendums on sensitive and important issues which are affecting people's legitimate and legal interests.

4) To ensure mechanisms for mass media in the formation, expressing public opinion and impact mechanism of "people know, people discuss, people do and people monitor" through public opinion. Mass media is not only the voice of the ruling party and the state, but also is the people's forum, expressing feelings and aspirations of the masses; including proposition of the matters which should be done, the matters which should be supplemented and completed.

5) To have the direction for periodic study on public opinion in terms of these values annually and must be conducted on a large scale, to find out evaluation of public opinion toward the goal of values.

\section{Acknowledgements}

This work was supported by Vietnam National Foundation for Science and Technology Development (NAFOSTED) [grant number I3.4-2011.09].

\section{References}

[1] Van Giau, T. (2011) Vietnamese’s Traditional Spiritual Values. National Political Publishing House, Hanoi.

[2] Hac, P.M. (2011a) Application of Ho Chi Minh thought for Summarization Building Vietnamese’s Common Values. Human Study Journal, 3, 3-10.

[3] Hac, P.M. (2011b) Axiology—Rationale Contributing in Summarization, Building Vietnamese’s Common Values Nowadays. Education Publishing House, Hanoi.

[4] Quy, H.S. (2005) Values and Asian Values. National Political Publishing House, Hanoi.

[5] Tan, P. (2011) Democracy in Innovation and Development Objectives. Journal of Philosophy, 6, 50-57.

[6] General Statistics Office (1999) Documents of the Grassroots Democratic Regulations. Statistical Publishing House, Hanoi.

[7] Nam, M.Q. (2000) The Role of Public Opinion in "People Know, People Discuss, People Do and People Monitor" Mechanism. Psychology Journal, 2, 50-54.

[8] Central Committee of the Communist Party of Vietnam (1982) Documents of the Secretariat Decided to Establish the Institute for Public Opinion under the Party Central Department of Propaganda and Education. Hanoi.

[9] Central Committee of the Communist Party of Vietnam (1992) Documents of the 3rd Plenum by 7th Central Executive Committee on Innovation and Regulation of the Party. Hanoi.

[10] Central Committee of the Communist Party of Vietnam (1995) Documents of the 8th plenum by the 7th Party Central 
Executive Committee on Building and Perfecting the Socialist Republic of Vietnam. Hanoi.

[11] Central Committee of the Communist Party of Vietnam (2007) Documents of the 5th Plenum of the 10th Party Central Committee on the Work of Ideology, Theory and Journalism. Hanoi.

[12] Central Committee of the Communist Party of Vietnam (2012) Documents of the 4th Plenum of 11th Party Central Committee on Some Urgent Issues in Building Party Currently, Accompanying Plan No. 08-KH/TW. Hanoi.

[13] Vietnam Government (2005) Information Development Strategy until 2010, Accompanying Decision No. 219/ QĐTTg of the Prime Minister. Hanoi. 
Scientific Research Publishing (SCIRP) is one of the largest Open Access journal publishers. It is currently publishing more than 200 open access, online, peer-reviewed journals covering a wide range of academic disciplines. SCIRP serves the worldwide academic communities and contributes to the progress and application of science with its publication.

Other selected journals from SCIRP are listed as below. Submit your manuscript to us via either submit@scirp.org or Online Submission Portal.
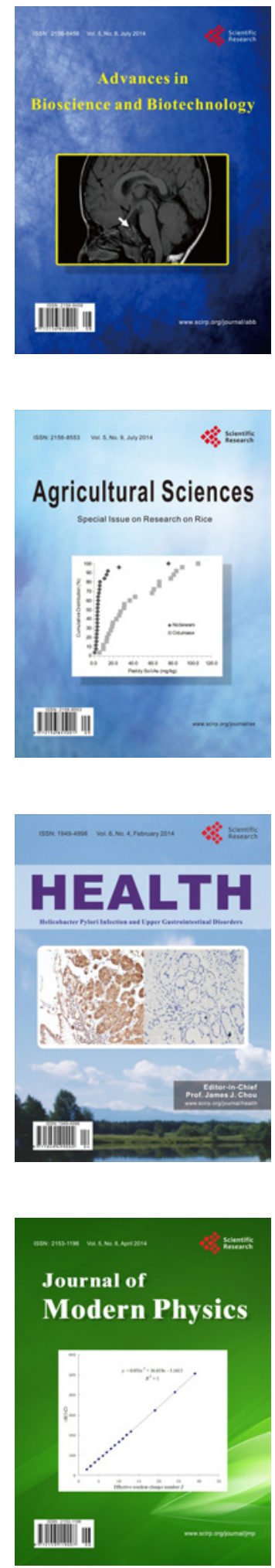
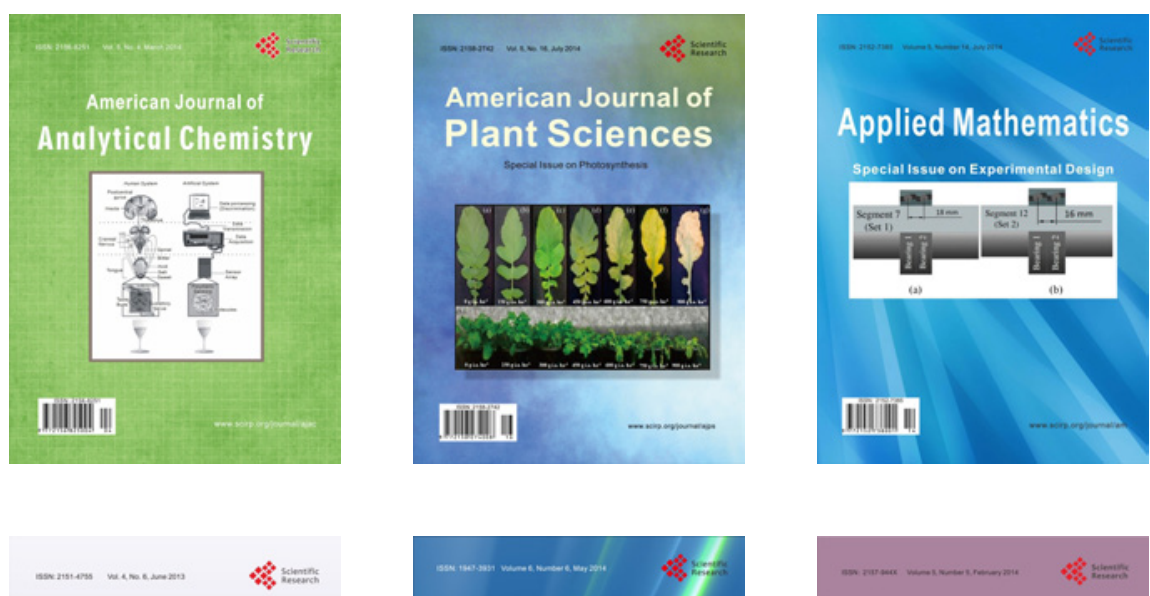

Creative Education
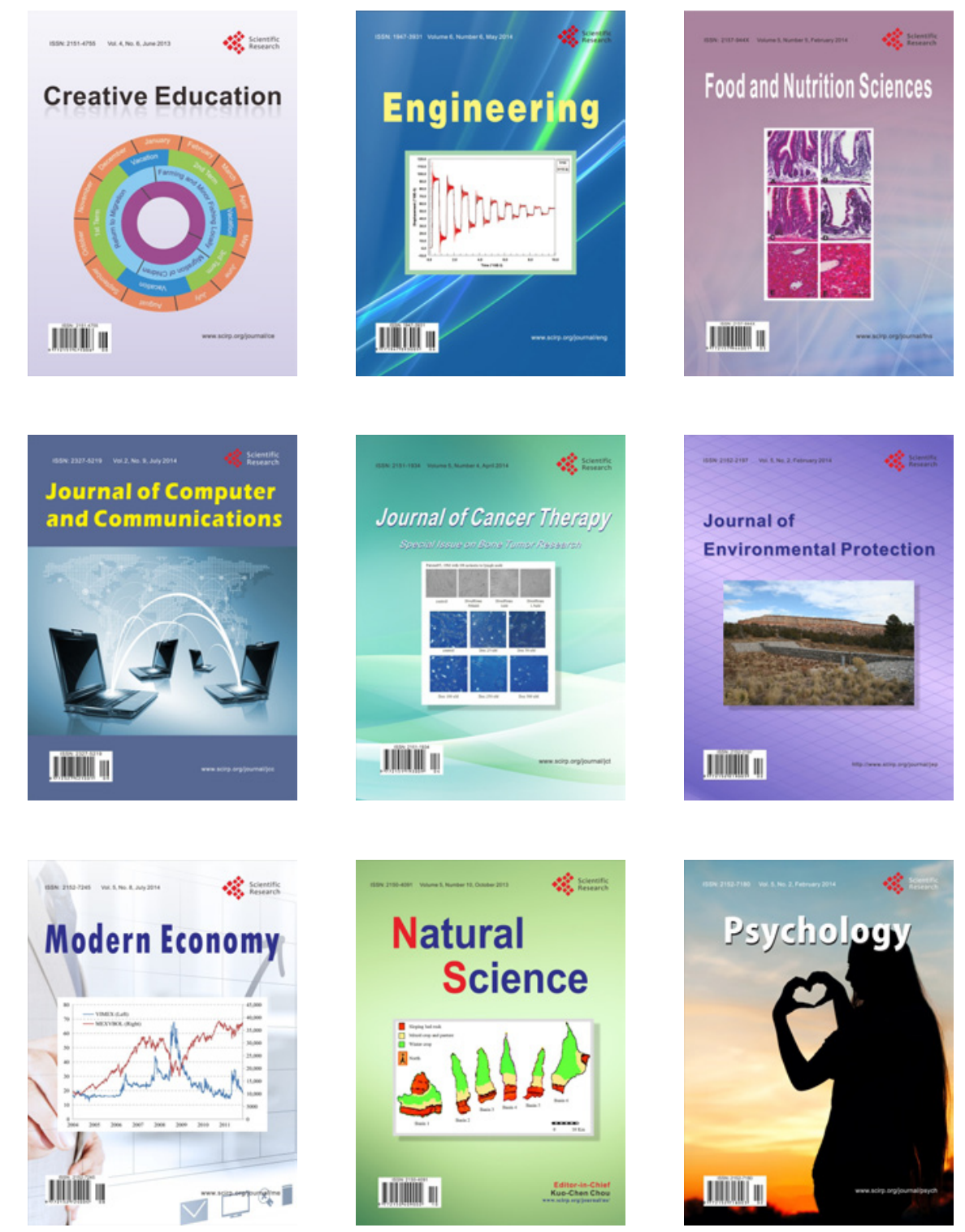